\title{
Blown Away in the Wind of Change: Can Extinct School Folktales be Awakened through Mathematics Storytelling in Nigerian Basic Education?
}

\author{
Joshua Abah Abah, Clement Onwu Iji, Benjamin Ogbole Abakpa \\ University of Agriculture, Makurdi, P.M.B. 2373, Benue State, Nigeria \\ e-mail: abahjoshua.a@gmail.com
}

\begin{abstract}
Abstrak
Bercerita sering dianggap sebagai transfer pembelajaran yang kuno, khususnya bagi anak-anak. Penelitian ini mengadopsi desain penelitian survei sederhana untuk mengeksplorasi sejauh mana guru menggunakan cerita di kelas matematika tingkat pendidikan dasar di Nigeria. Penelitian ini dimulai dengan perumusan premis mengenai cerita tradisional yang semakin ditinggalkan oleh perubahan yang disebabkan karena penggunaan teknologi yang semakin pesat di suatu negara. Subjek penelitian ini adalah 38 guru matematika yang dipilih secara acak pada Sekolah Dasar Makurdi di Benue State, Nigeria. Analisis data diperoleh melalui Basic mathematics Storytelling Investigation (BMSI) yang mengungkapkan bahwa meskipun tingkat kesadaran bercerita yang tinggi sebagai pendekatan pengajaran di antara guru matematika, hanya sedikit 37\% yang menggunakan cerita di kelas matematika mereka. Analisis tematik tambahan dari cerita yang dideskripsikan oleh guru menunjukkan bahwa cerita dapat digunakan untuk mengilustrasikan tujuan pembelajaran dan memotivasi peserta didik untuk aktif dalam pembelajaran. Hasil penelitian yang tidak sengaja diperoleh melalui metode kualitatif mengungkapkan bahwa pola khusus dari cerita yang diberikan oleh guru matematika cenderung jauh dari cerita rakyat lokal dan tradisi lisan. Selain itu, terdapat indikasi bahwa melalui ajakan secara sadar yang tepat, guru matematika SD tertarik untuk mengunakan cerita dalam praktik mengajar ke depan.
\end{abstract}

Kata kunci: Bercerita, Pendidikan Dasar Nigeria, Cerita Rakyat, Etnomatematika, Budaya

\begin{abstract}
Storytelling has been severally regarded as the oldest method of instruction delivery, particularly for children. This study adopts a simple survey research design to explore the extent of storytelling usage by teachers in the mathematics classroom at the primary education level in Nigeria. The investigation was conducted on the premise that traditional folktales are heading down the path to extinction and are steadily being blown away in the wind of change being fanned by increasing technology penetration in the country. The participants of the study are 38 mathematics teachers drawn randomly from primary schools within Makurdi metropolis of Benue State, Nigeria. Analysis of data obtained through the Basic mathematics Storytelling Investigation (BMSI) revealed that despite the high level of awareness of storytelling as a teaching approach among mathematics teachers, only a meager $37 \%$ make use of stories in their mathematics classroom. Additional thematic analysis of stories described by the teachers showed that stories were used to illustrate learning points and motivate learners to action within the instructional context. An unintended outcome from the qualitative methods unveiled specific patterns of stories used by the mathematics teachers that are far from local folktales and oral traditions. There was also an indication that with an appropriate awareness campaign, primary mathematics teachers intend to use storytelling in their future teaching practice.
\end{abstract}

Keywords: Storytelling, Nigerian Basic Education, Folktales, Ethnomathematics, Culture

How to Cite: Abah, J. A., Iji, C. O., \& Abakpa, B. O. (2018). Blown away in the wind of change: Can extinct school folktales be awakened through mathematics storytelling in Nigerian basic education? International Journal on Emerging Mathematics Education, 2(2), 165-178. http://dx.doi.org/10.12928/ijeme.v2i2.10561 


\title{
INTRODUCTION
}

\author{
Narrator : Story? Story? \\ Students : Story! \\ Narrator : Once upon a time? \\ Students : Time! Time!
}

That was a fragment of an exciting routine before the commencement of every story within the "story-time" in our local primary school. The routine is now remembered by only those who started formal education before the onset of the new millennium in Nigeria. The teacher used story-time to gain the eagerness of all students mainly because it was the last activity of the school day before dismissing for home. For many children, it was the ideal form of relaxation, freedom, and play. What many of these children failed to notice at the time is the subtle role this storytelling time played in inculcating the right cultural values and enriching all forms of learning within the school setting. As adults, we are just beginning to appreciate the significance of story-time on the class timetable, but there is no more now. It is just dawning on us that our own children may not be so privileged to take turns preparing for story-time. They may not have the opportunity to relate a folktale learned within the extended family circle to an expanded classroom audience where they could confidently make their voices heard. If not awaken in other forms, the loss of storytime will remain a great loss to primary education in Nigeria.

Primary education in Nigeria comprises a continuous nine-year education for children age 4 to 12, with the first three years (lower basic level) for Primary 1 to Primary 3, another three years (middle basic level) for Primary 4 to Primary 6, and the final three years (upper basic level) for Junior Secondary School 1 to Junior Secondary School 3. At the Junior Secondary School 3, the students join for the Basic Education Certificate Examination (BECE) qualifying them for entry into Senior Secondary School, non-professional jobs, or even politics. Within this educational system, there is a single composite curriculum for mathematics, running sequentially from one level to the other. Thus, the basic mathematics refers to the mathematics taught to the students within the nine-year system, and consequently, the teachers of the subject within this system are referred to as the basic mathematics teachers. In terms of comparison, the Nigerian Primary Education is the equivalent of Elementary School System in other countries.

The type of stories narrated by teachers and students during story-time is meant to convey historical messages, encourage the students to academic valor, and deter the cultivation of wrong attitudes and deviant behaviors. Often, the sequence and style are not of great concern in this type of storytelling as language, non-verbal communication, and critical thinking. As such, though students may not be intrigued with the moral, cultural values in stories, they unconsciously assimilate these values by means of narration and role-playing (Hourani, 2015). Stories take students on a journey that inspires them to learn about themselves and the world around them.

Basically, storytelling is retelling a tale to one or more listeners through voice and gestures (Utley, 2012). It is not the same as reading a story to oneself or others aloud. It is different from reciting a piece of memory. Utley (2012) adds that the storyteller creates a series of mental images associated with words, while the audience stares, smiles or leans forward to hear more. The narrative flows in a way that each listener can form unexpected connections and learn appropriately. Storytelling

IJEME, Vol. 2, No. 2, September 2018, 165-178 
conveys folklore, a body of expressive culture within a particular population comprising the tradition of that culture, subculture, or group. Folklore, in turn, includes among other things, folktales, riddles, proverbs, myths, songs, legends and superstition (Ezeigbo, 2013). Storytelling has been successfully deployed to interpret the universe, resolve natural and physical phenomena, teach morals, maintain cultural values, pass on methods of survival, and to praise God (Utley, 2012). Professional storytellers believe in the power of story to heal the world and foster good retention (Baldasaro et al., 2014). In storytelling, there is a coming together, a removal of boundaries, and a total concentration and absorption of the spoken word (Goral \& Gnadinger, 2006).

Despite the amazing power of storytelling, present realities in Nigerian Primary Education constitute a grave challenge. The complexity and dynamism of the present Nigerian society bring about innovation in the production, transmission, retrieval, and performance of culture (Sesan, 2014). Apart from the resulting worrisome levels of classroom inattentiveness (Agbo-Egwu et al., 2017) and plausible digital amnesia (Agbo-Egwu et al., 2018), the technological advancement is beginning to introduce a form of postmodern social codes, thereby relegating ordinary local activities, including storytelling, to the background. Folklore is disappearing fast with the incursion of modernity to the extent that many Nigerian youths have lost touch with their ethnic folklore and culture (Ezeigbo, 2013). It is a good thing that the curriculum reacts to the demands of the time, but reactions that ended up in pushing out vital aspects of culturally relevant instructional technique must be eschewed. For instance, Abah (2016) hinted that there is the indication that very little elements of history are being embedded in classroom instruction considering how General History as a subject has fared in the development of curriculum in Nigeria.

However, with the more impressive impact being realized from researches into storytelling, there is the need to herald an awakening of this vital part of our tradition, particularly in mathematics education. The power of stories to convey mathematical concepts and ideas to children has long been recognized by educationists. Instead of blaming advances in science and technology for the cultural woes of this era, some mathematics educators and practitioners are discovering that stories are a great way to make science, technology, engineering and mathematics (STEM) educational ideas accessible and concrete to learners who might not think those kind of technical studies are for them (Inan, 2015). By connecting a mathematical concept to young children through narratives, it is possible to truly engage their emotions, and to help them understand the power of the ideas being explored. This possibility has been empirically attested to by Albool (2013), and many other researchers (e.g. Abah, 2017) who obtained research findings establishing that using storytelling strategy in teaching mathematics increased students' ability to solve higher order problems.

With respect to successes observed via storytelling in mathematics, very little evidence from within Nigeria is available (Ogbu, 2018; Abah, 2016). Specifically, outside the quasi-experimental setup (for instance, Adetunji et al., 2013; FrederickJonah \& Akinsola, 2015), little is known about the regular or irregular use of stories by teachers in the mathematics classroom (Bature, 2014). The level of awareness about the mathematical storytelling approach among Nigerian mathematics teachers at the primary education level is sparingly treated in available literature. If stories are being deployed as instructional strategies in basic mathematics, what are the various style of narration used? These and other pertinent concerns form the basis of this inquiry. 
The following research questions guided this study is what is the level of awareness of storytelling as an approach to teaching basic mathematics among mathematics teachers, how frequent do basic mathematics teachers deploy storytelling in the classroom, what is the pattern of storytelling used by basic mathematics teachers, and what percentage of basic mathematics teachers considered using stories to teach mathematics in the future.

\section{RESEARCH METHOD}

This study adopts a survey research design to investigate the use of storytelling by mathematics teachers at the primary education level in Nigeria. Primary education in Nigeria covers the first nine years of formal education in the country, with three distinct stages. The first three years (Primary 1 to Primary 3) constitute the lower basic level. Primary 4 to Primary 6 makes up the middle basic level, while Junior Secondary School 1 to 3 constitutes the upper basic level. The Basic Education System ensures a seamless transition from the primary school to the secondary school and culminates in the Basic Education Certificate (BEC) obtained at the end of the nine years.

This study was conducted in Makurdi metropolis of Benue State, Nigeria. The population of basic mathematics teachers in the study area is 825 . The sample for this study comprises 38 basic mathematics teachers randomly selected from across the three tiers of primary education in Makurdi metropolis. The researcher-developed instrument, basic mathematics Storytelling Investigation (BMSI) was administered to all the mathematics teachers in the sample on a voluntary basis. The BMSI is a simple investigation developed in line with the focus of this study. Outside basic information (name of school and gender) about the respondent, it comprises just four questions. The first item is a simple Yes - or - No probe on awareness of storytelling as an approach to teaching mathematics. The second question initially asked if the respondent has used storytelling in the classroom before and later demanded the frequency of usage on a four-point scale (Very Frequent $=4$; Frequent $=3$; Fairly Frequent $=2$; Not Frequent $=1$ ). The third prompt is for the respondent to provide a brief description of any story recently used in the teaching of mathematics. The fourth question simply asked if the respondent will consider using stories to teach mathematics in the future. The researcher collected the instrument (BMSI) directly from the mathematics teachers.

Simple percentages were used to answer research questions one, two and four, with additional pie charts used in presenting the results where necessary. The frequency rating scale for research question two was also analyzed using mean and standard deviation, with the decision benchmark being a mean of 2.50 . A mean above 2.50 indicates "frequent" usage of storytelling while a mean below 2.50 indicates a "not frequent" usage. Research question three was answered via qualitative data reduction strategies which focus on managing, categorizing and interpreting the written descriptions of stories to identify specific themes and patterns (McMohan \& Garza, 2017; and Abakpa, Abah \& Agbo-Egwu, 2017).

\section{RESULTS AND DISCUSSION}

The results of this study are presented according to the stated research questions. 
The Level of Awareness of Storytelling as an Approach to Teaching Basic Mathematics among Mathematics Teachers

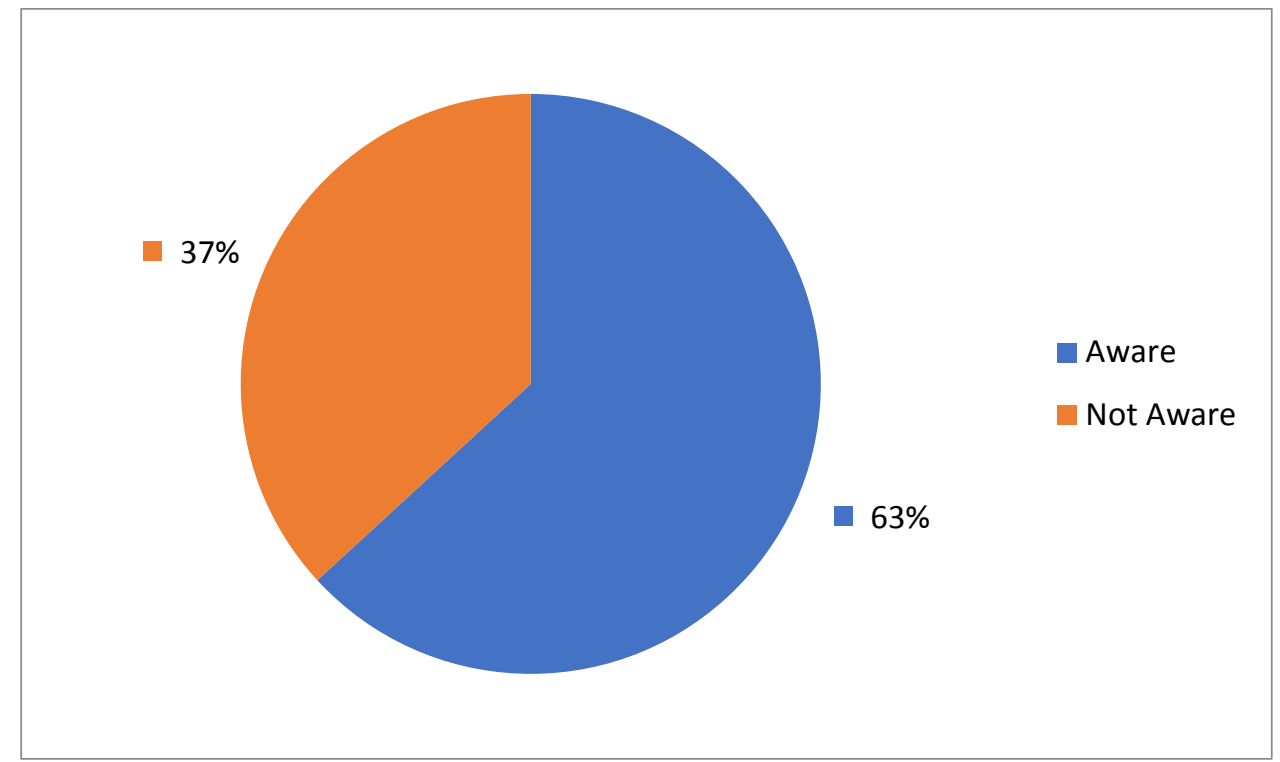

Figure 1. Level of awareness of storytelling as a teaching approach

The $63 \%$ of basic mathematics teachers are aware of storytelling as a teaching approach while $37 \%$ are not. This implies that there is a high level of awareness of storytelling as an approach to teaching mathematics among mathematics teachers at the primary education level. The result is shown in Figure 1.

\section{The Intensity of Basic Mathematics Teachers Deploy Storytelling in the Classroom}

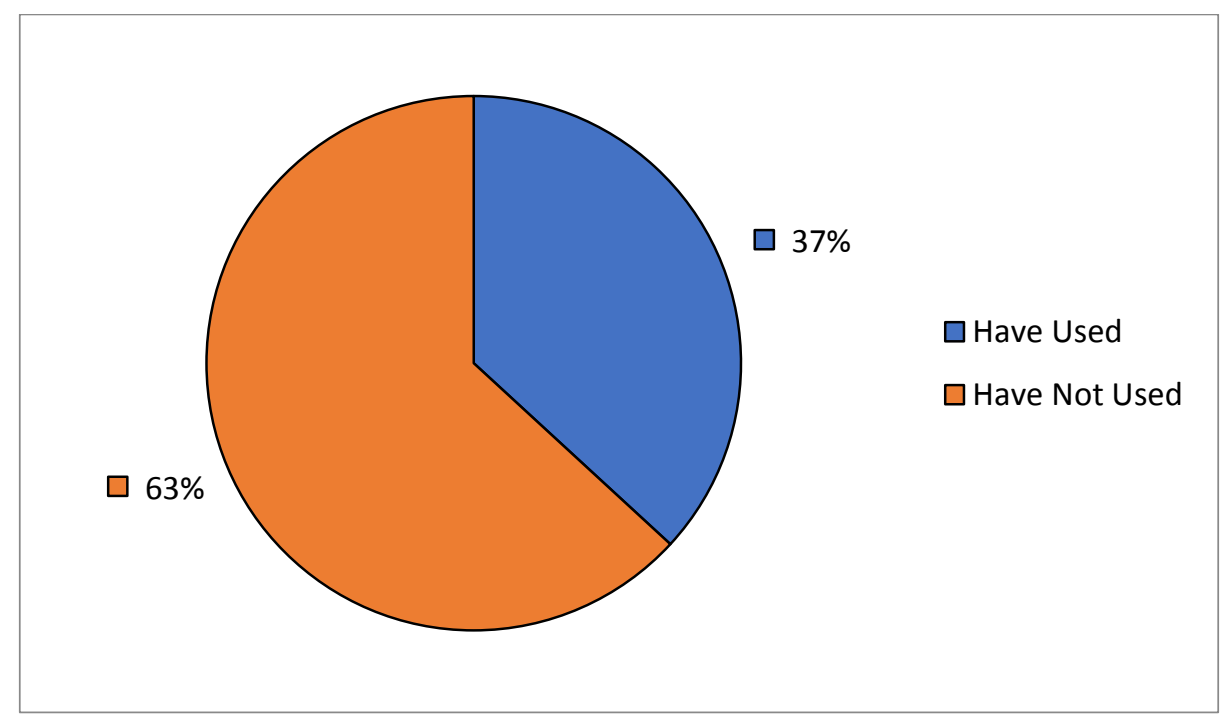

Figure 2. The proportion of mathematics teachers who have used storytelling in mathematics class

The $37 \%$ of basic mathematics teachers have used storytelling in their mathematics class. Conversely, $63 \%$ of the teachers have not used storytelling as a 
teaching approach in mathematics. The pie chart is shown in Figure 2. The frequency of usage (in percentages) of storytelling by the $37 \%$ of basic mathematics teachers who use the approach is shown in Figure 3.

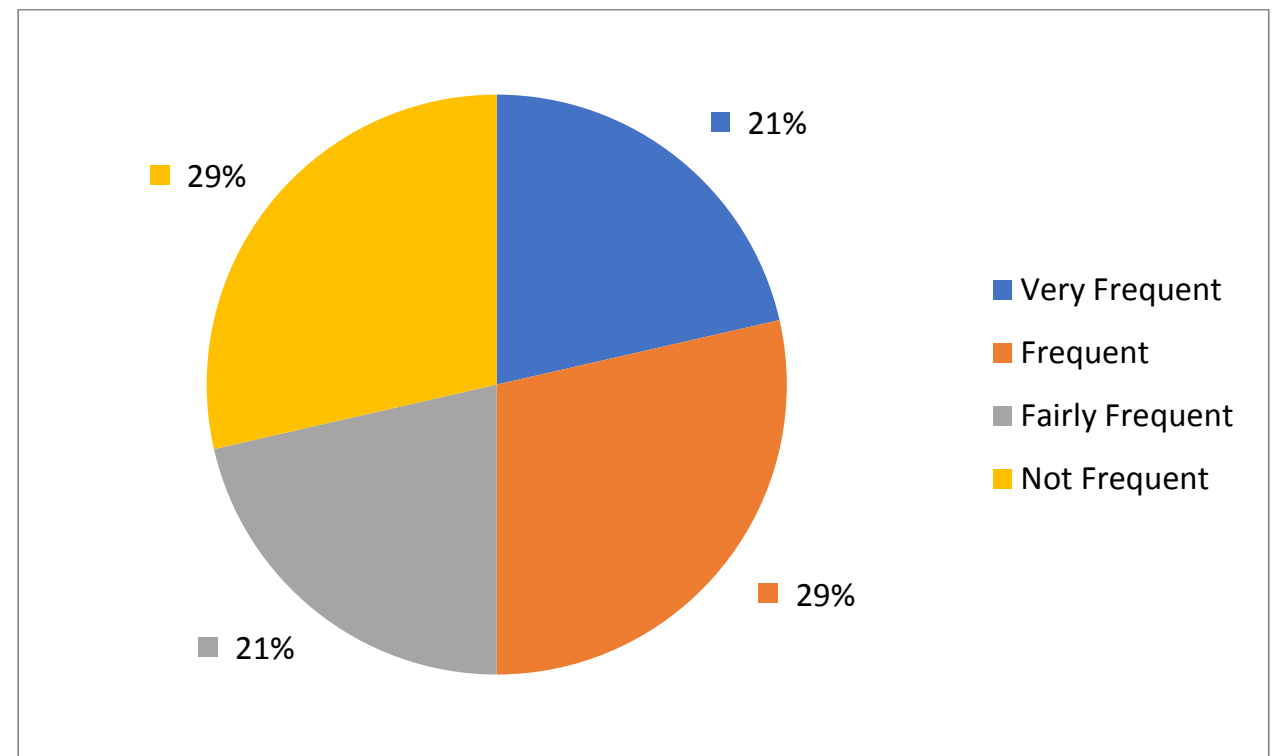

Figure 3. The frequency of usage of storytelling in the classroom by basic mathematics teachers

When analyzed as a four-point scale, the mean and standard deviation for the item on the frequency of usage of storytelling in teaching mathematics are as shown in Table 1.

Table 1. Mean and standard deviation of basic mathematics teachers' response to the frequency of usage of storytelling in teaching mathematics

\begin{tabular}{llll}
\hline \multicolumn{1}{c}{ Item } & Mean & Std. Dev. & Remark \\
\hline $\begin{array}{l}\text { How frequently do you use storytelling in } \\
\text { teaching mathematics? }\end{array}$ & 2.43 & 1.16 & Not Frequent \\
\hline
\end{tabular}

The data in Table 1 shows that the item mean of 2.43 is below the decision benchmark of 2.50, indicating basic mathematics teachers do not frequently use storytelling in teaching mathematics.

\section{Story Telling Pattern Used by Basic Mathematics Teachers}

Three key themes were deduced from the short stories described by the basic mathematics teachers who participated in this study, pointing to three major patterns of the usage of storytelling in the Basic mathematics classroom.

\section{Story to Motivate}

Some of the Basic mathematics teachers who participated in this study use stories in the mathematics classroom to motivate pupils to take the right step in solving mathematical problems. One of the teachers described a story titled "The Careless Nurse" thus:

A nurse was given a drug prescription for a patient in a hospital. The doctor wrote II-II-II on the sachet containing the tablets. The nurse carelessly interpreted the 
prescription as eleven pills in the morning, eleven pills in the afternoon, and eleven pills in the evening. She administered the drug wrongly and the patient suffered the severe effect of the over-dosage.

Using this story, the teacher taught the pupils an important lesson on personal carelessness and the need to learn mathematical numerals and symbols correctly. In a way, the listeners are motivated to take seriously every step of their mathematics problem solving routines.

\section{Poetic Story}

Basic mathematics teachers sometimes present stories in the form of short poems. One of the teachers presented a short poem which always comes in handy "telling us to reason before giving an answer. We should not guess." The poem goes thus:

Think and talk

Think and talk

Like a clock

\section{Story to Illustrate}

A good number of stories deployed in the mathematics classroom at the basic education level are meant to illustrate specific learning points in the course of lesson delivery. A Junior Secondary School mathematics teacher described his story thus:

There was a girl whose name is Linda. She loves eating mango fruits. One day she stood 15 meters away from the mango tree in the middle of their farm, having sighted a ripe mango fruit hanging from a branch at the top of the tree. She then called on her brother, James, to assist her. She showed the particular fruit to her brother by pointing up and directing his sight through the appropriate angle.

This teacher explained that "the raising of her eye from the normal position to the top of the mango tree is what is known as Angle of Rotation." Through this story, the teacher provided vivid illustrations of the concept being taught and drew a sketch of the scenario on the board for students to see.

Another teacher gave a depiction of his usage of storytelling in the following descriptions:

The last story I used in teaching mathematics was when I used two of my students to illustrate the topic Fraction. The story was about the two students being given one apple fruit to share equally. They shared it into two which implies that each student got half of it. If the students are eight, then each student would have $\frac{1}{8}$ of the apple fruit.

Another topic I used a story to teach in mathematics was Ratio. It was about a 3year old boy trying to share a cash gift of $\$ 250.00$ with his younger brother who is 2 years old, according to their ages. In other to have the accurate amount of money according to their ages, he would add both their ages together, divide the amount of money by the sum of their ages and then multiply the result by each of their ages separately. In this way, the boy will arrive at the accurate amount of money according to their ages.

In a similar pattern, another teacher from a nursery and primary school illustrated her teaching of Ratio with this story he described in his own words:

The story I used recently in teaching mathematics was on Ratio. A ratio is a simple form of expressing the size of one item relative to another. For instance, if a mother gives two of her children 36 oranges to share, it is common in our African 
tradition for the older child to receive more than the younger. The mother decides to give the older child two oranges for every one orange given to the younger child. At the end of the day, the older child would receive 24 oranges while the younger would receive 12 .

This basic mathematics teacher added that "in mathematics, we say the oranges were shared in the ratio of 2:1." While indicating his intention to continue to use storytelling in the future, the same teacher provided the following details:

Mathematics is a subject that has many real-life applications. To reduce the complexity of this subject, I think it is very necessary to give familiar stories related to the topic being taught so as to make learning more concrete to the children.

One of the participants of this study related a story to illustrate the adjacent and opposite angles in right-angled triangles. The story goes thus:

A man was looking for a church he has been directed to see the Senior Pastor. He went to the neighborhood of the church and asked a woman to direct him to the church. Unfortunately, the woman didn't know the name of the church but she knows there is a church in the vicinity. She gave the direction to the church as follows:

Have you seen that house? Go straight, turn left at the house and proceed straight and turn left again to see one "Mama Pot" (local eatery). You will then see a red gate opposite the eatery. That the church. The man followed this direction, walked and walked but couldn't find the church. The woman's directions to the church were so confusing that the man ended up in the same place where he started his search.

Fortunately, he saw a member of the church who gave the same directions, but as follows:

Go to the end of this street and take left. Count three houses adjacent the green gate immediately after you turn left. There is a compound opposite a red-gate house on the adjoining street. That's the church.

Another basic mathematics teacher emphasized that he sometimes built his illustrations around "the use of mathematics at home, particularly in the kitchen." He related that he often refers to details of the measure of ingredients used in cooking a certain type of soup, noting the number of countable items like Maggi cubes, onion bulbs, and tomato fruits.

\section{The Percentage of Basic Mathematics Teachers Considered using Stories to Teach Mathematics in the Future}

The $82 \%$ of basic mathematics teachers considered using stories to teach mathematics in the future, while $18 \%$ of basic mathematics teachers do not think they will consider using stories to teach mathematics (the data displayed in Figure 4). 


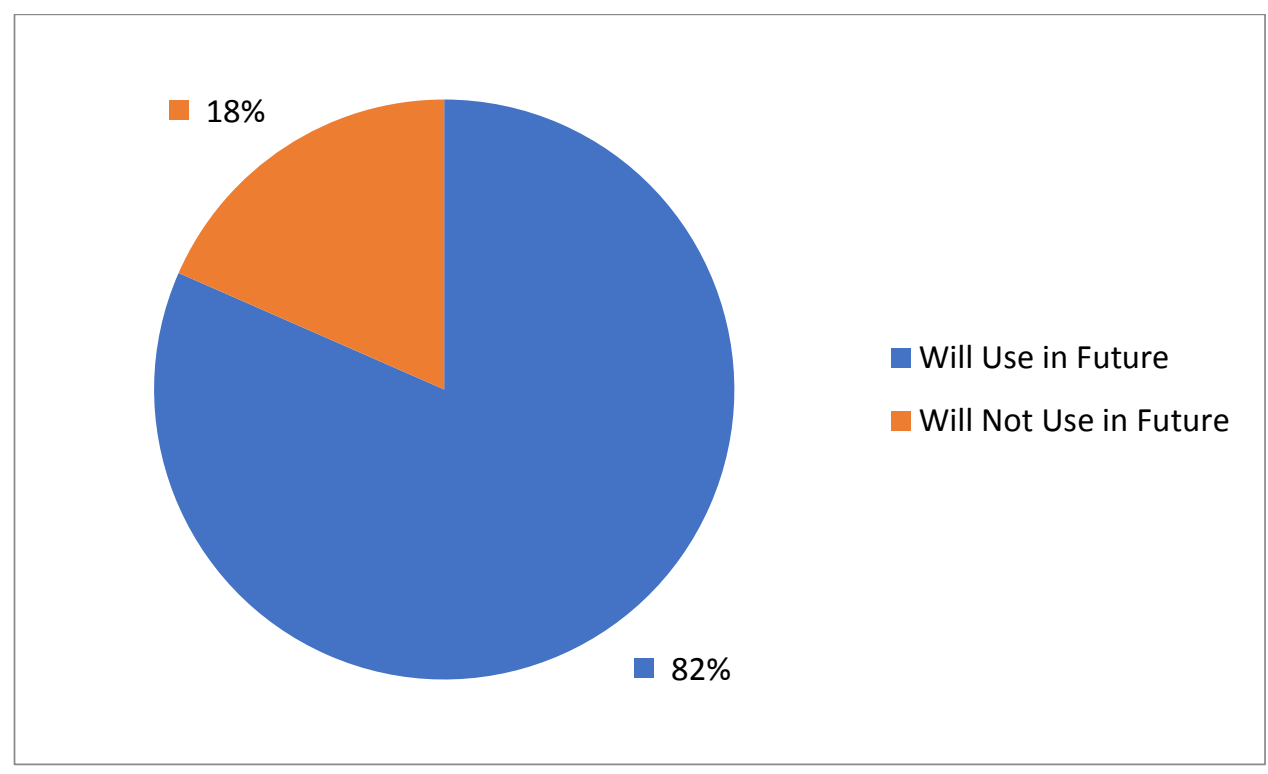

Figure 4. Percentage of basic mathematics teachers who considered using stories to teach mathematics in the future

\section{Discussions}

The outcomes of this study have indicated that a good proportion of basic mathematics teachers (63\%) are aware of storytelling as a teaching approach. This high level of awareness depicts the potential storytelling holds in adding aesthetic value to mathematics as a school subject. Evidently, this result supports the rationale for storytelling being used as a teaching method for centuries. Despite the recorded awareness level of the relevance of storytelling in mathematics education, only a meager $37 \%$ of basic mathematics teachers have deployed the approach in instructional situations. This particular statistic does not put Basic mathematics teachers from the study area in good light as it portrays a general lack of creativity, low levels of initiative and stereotypical ineptitude. This low usage was even made worse when taken in the light of the dismal frequency of usage of storytelling in teaching mathematics. The results displayed in Table 1 indicate that teachers do not frequently put to use this old and proven approach to learning in primary education. The implication is that school children are being denied the specifics of moral choices in situations with ethnocultural context thereby depriving them of the aesthetics of personal engagement (Sushkova et al., 2018).

The outcomes on the pattern of storytelling used by basic mathematics in Nigeria reveal that stories are often told to illustrate learning points and motivate learners into action within the instructional context. In other words, storytelling encourages discussion, improves listening skills, creates enthusiasm or excitement for study, and develops creativity. The use of stories from within the students' culture and previous knowledge contributes greatly to the students' learning process, help them better understand the study material, raise their motivation and, ultimately, improve their achievement in mathematics (Fouze \& Amit, 2018). In line with Abah (2018), the poetic stories sometimes deployed by some teachers provide alternative discourse in which learners could explore mathematical ideas from popular songs and lyrics, strengthen students' cognitive understanding of mathematical concepts and 
simultaneously bolster students' confidence in carrying out mathematical operations. The use of poems in primary education classroom contributes to strategies of learning and teaching of mathematics in motivational and humorous ways, thereby reducing anxiety and fear of mathematics and building positive attitudes and beliefs (Chirume, 2018). These outcomes agree with findings of Farlow (2018) that poems and stories are intended to motivate early learners of mathematics.

Although low patronage of storytelling was earlier observed among Basic mathematics teachers, further investigation (shown in Figure 4 ) reveals that $82 \%$ of Basic mathematics teachers considered using stories to teach mathematics in the future. The reason for this level of interest is not far-fetched since one of the participants of this study specifically noted that to reduce the complexity of the subject, it is necessary to present familiar stories related to the topic being taught so as to make learning more concrete to the children. Contents presented via stories create a real-life context, which is close to the child and excites curiosity and interest in learning of abstract mathematical concepts (Maricic et al., 2018). Evidently, only a high level of coordination on the part of the mathematics teacher can prevent mathematics instruction from being reduced to mere data transmission, a process in which there is no sharing of excitement and wonder (Abah, 2016). The teacher of mathematics is expected to first develop himself or herself at the personal level in the art of building open and honest intellectual relationships with students by leveraging on the connecting power of rudimentary mathematical artifacts embedded in stories (Abah, 2018).

In a present-day society which is fully technological and tends to automate everything, no one can deny the importance of creativity as a necessary and useful attribute of knowledge (Kelemen, 2017). Despite the sophistication of the information age, the basics of creative thinking available through the craft of storytelling are essential for the cognitive growth of children. Apart from aiding academic development, the usage of storytelling communicates key societal values that will stand the test of time (Amaele \& Okenwa, 2018; Farlow, 2018). When taken together, the findings of this present study are consistent with the results obtained by Casey et al. (2004) who observed that storytelling within mathematics improves students' problem-solving skills. Storytelling can be leveraged upon via the ingenuity of the mathematics teacher to guide students in numerous ways and possibly in ways that prevent students from searching for their own solutions that may be erroneous in a problem-solving context.

One unintended outcome of the thematic analysis employed to answer research question three is the realizations that most of the stories used by the Basic mathematics teachers who participated in this study are from the traditional folktales that characterized the story-time of earlier formal education in Nigeria. It is noteworthy that many original folktales and oral traditions have been re-packaged in storybooks. Despite this new aspect of the presentation of ethnocultural content, the innovative mathematics teacher can distill his or her mathematics-related story from any source for the purpose of re-presentation to a mathematics class. As noted by Abah (2016), even this must be done without falling for the usual recency bias that is common in referring to older sources. By telling and retelling tales about the ancient peoples of particular cultures, heroes and heroines of local histories, magical worlds, and other fairy tales, children are provided the opportunity to understand realities outside their immediate environment and decode elements relevant to mathematical knowledge.

IJEME, Vol. 2, No. 2, September 2018, 165-178 


\section{CONCLUSION}

This study has explored the use of stories by teachers in the mathematics classroom at the primary education level in Makurdi, Benue State, Nigeria. The investigation was predicated on the supposition that traditional folktales are rapidly heading down the path to extinction, steadily being blown away in the wind of change being stoked by increasing levels of technology penetration in the country.

The findings from this simple survey indicate a high level of awareness of storytelling as an approach to teaching mathematics among Basic mathematics teachers, although only a meager $37 \%$ are presently utilizing this time-proven augmentation to mathematics instruction delivery. Even among those making use of the approach, the patterns of stories are far from traditional folktales and oral traditions. Trickster stories using animal characters such as popular Tortoise's stories, and tales of heroics from students' local folklore can be innovatively crafted into classroom activities to augment the understanding of mathematical procedures and problem-solving strategies. The study unveils a high level of interest on the part of the teachers to make effective use of storytelling in their teaching practice. This particular expression of hope depends heavily on creating the necessary awareness on the relevance of stories to mathematics teaching. On this ground, the present study recommends a concerted effort by all stakeholders within the Basic Education sector to mobilize for a massive awareness campaign on the use of stories in teaching. Particular searchlight should be beam on the gradual erosion of community and cultural values occasioned by the fading away of traditional folktales. Such an awareness campaign can make a case for the return of story-time to the Basic School timetable.

Despite the robustness of this study, considering the very small sample size used, it may be only a scratch on the surface of the potential gains derivable from the storytelling approach in Nigerian Basic Education. Future studies may seek to develop easily and adaptable lesson plans and mini-programmes for the usage of storytelling in the Nigerian classroom.

\section{REFERENCES}

Abah, J. A. (2016). Recency bias in the era of big data: The need to strengthen the status of history of mathematics in Nigerian schools. Advances in Multidisciplinary Research Journal, 2(4), 241-248.

Abah, J. A. (2017). Viewing basic math through the lens of history: Undergraduates' reflective learning in a history-augmented mathematics classroom. Waikato Journal of Education, 22(4), 33-48.

Abah, J. A. (2018). A mathematical portrayal of a Christmas carol for Nigerian basic education: The mathematics in the twelve days of Christmas. Indian Journal of Arts, 8, 43-57.

Abakpa, B. O., Agbo-Egwu, A. O. \& Abah, J. A. (2017). Emphasizing phenomenology as a research paradigm for interpreting growth and development in mathematics education. ABACUS: The Journal of the Mathematical Association of Nigeria, 42(1), 391-405.

Adetunji, A. A., Bamidele, E. F. \& Awodele, B. A. (2013). Effects of historical simulations as narrative and graphic organizers on Nigerian junior secondary school 
students' learning outcomes in basic science. Mediterranean Journal of Social Science, 4(2), 743-752.

Agbo-Egwu, A. O., Abah, J. A. \& Anyagh, P. I. (2017). Sustaining attention in a rapidly changing world: A survey of the status among mathematics education students in Nigeria. Benue Journal of Mathematics and Mathematics Education, 2(4), 13-21.

Agbo-Egwu, A. O., Abah, J. A. \& Anyagh, P. I. (2018). The influence of smartphone overdependence on the recall of basic mathematics among mathematics education students in a Nigerian university. Science \& Technology, 4, 97-105.

Albool, R. (2013). The storytelling strategy in teaching mathematics may increase students' abilities to solve high order questions and word problems. EDULEARN13 Proceedings, IATED, 2361-2367.

Amaele, S. \& Okenwa, U. (2018). A philosophical reflection on the gap between the theory and practice of values in Nigeria. International Journal of Education and Evaluation, 4(3), 56-64.

Baldasaro, M. M., Maldonado, N. \& Baltes, B. (2014). Storytelling to teach cultural awareness: The right story at the right time. Learning Landscapes, 7(2), 219-232.

Bature, I. J. (2014). Productive pedagogies for reforming secondary school mathematics classroom practice in Nigeria. Dissertation. Perth: Curtin University.

Casey, B., Kersh, J. E. \& Young, J. M. (2004). Storytelling sagas: An effective medium for teaching early childhood mathematics. Early Childhood Research Quarterly, 19, 167-172.

Chirume, S. (2018). Learning mathematics: Like proposing to a girl. Eurasia Journal of Mathematics, Science and Technology Education, 14(2), 605-607.

Ezeigbo, A. T. (2013). The relevance of oral tradition: Folklore and the education of Nigerian youths. Contemporary Experiences: Journal of African Humanities, 1(1), 128-140.

Farlow, S. J. (2018). Writing and storytelling as an aid in learning math. Eurasia Journal of Mathematics, Science and Technology Education, 14(2), 579-584.

Fouze, A. Q. \& Amit, M. (2018). Development of mathematical thinking through integration of ethnomathematics folklore game in math instruction. Eurasia Journal of Mathematics, Science and Technology Education, 14(2), 617-630.

Frederick-Jonah, T. M. \& Akinsola, M. K. (2015). Enhancing pupils' knowledge of mathematical concepts through game and poem. IOSR Journal of Research \& Method in Education, 5(2), 60-66.

Goral, M. B. \& Gnadinger, C. M. (2006). Using storytelling to teach mathematics concepts. $A P M C, 11(1), 4-8$.

Hourani, R. B. (2015). Folktales, children's literature and national identity in the United Arab Emirates. The Looking Glass, 18(1).

Inan, C. (2015). A digital storytelling study project on mathematics course with preschool pre-service teachers. Educational Research Reviews, 10(10), 14761479.

Kelemen, G. (2017). Creativity, performance and emotional balance. Journal Plus Education, 18(2), 38-46. 
Maricic, S. M., Stakic, M. M. \& Malinovic-Javanovic, N. T. (2018). The role of literary content for children in preschool mathematics education. Eurasia Journal of Mathematics, Science and Technology Education, 14(2), 631-642.

McMohan, S. K. \& Garza, R. (2017). Fostering pre-service teachers' development: Engagement in practice and learning. Current Issues in Education, 19(3), 1-17.

Ogbu, S. U. (2018). Deconstructing the role of storytelling in the preservation of indigenous Nigerian traditions. Advances in Social Science Research Journal, 5(1), 148-156.

Sesan, A. A. (2014). Yoruba folktales, the new media and postmordernism. Khazar Journal of Humanities and Social Sciences, 17(2), 74-87.

Sushkova, I. V., Gerasimova, E. N. \& Promina, A. N. (2018). Specifics of moral choices made by children aged 6 to 8 years in situations with ethnocultural context. International Journal of Cognitive Research in Science, Engineering and Education, 6(1), 1-11.

Utley, 0. (2012). Keeping the tradition of African storytelling alive. Retrieved from http://teachers.yale.edu/curriculum/viewer/initiative_09.01.08_u. 
